\title{
EVALUATION OF THE COURTSHIP AND OF THE HYBRID MALE STERILITY AMONG Drosophila buzzatii CLUSTER SPECIES (DIPTERA, DROSOPHILIDAE)
}

\author{
MACHADO, L. P. de B., ${ }^{1}$ CASTRO, J. P. de ${ }^{2}$ and MADI-RAVAZZI, L. ${ }^{2}$ \\ ${ }^{1}$ Faculdade de Medicina, Departamento de Genética, Universidade de São Paulo, Ribeirão Preto \\ ${ }^{2}$ Instituto de Biociências, Letras e Ciências Exatas, Departamento de Biologia, Universidade Estadual Paulista, \\ São José do Rio Preto \\ Correspondence to: Lilian Madi Ravazzi, Instituto de Biociências, Letras e Ciências Exatas, Unesp, Rua Cristóvão \\ Colombo, 2265, CEP 15054-000, São José do Rio Preto, SP, Brazil, e-mail: lilian@bio.ibilce.unesp.br \\ Received July 30, 2001 - Accepted September 17, 2001 - Distributed November 30, 2002
}

(With 1 figure)

\begin{abstract}
In the Drosophila repleta group the establishment of subgroups and complexes made on the basis of morphological and cytological evidences is supported by tests of reproductive isolation. Among species in the repleta group, the buzzatii cluster, due to its polymorphism and polytipism, is an excellent material for ecological and speciation studies. Some interspecific crosses involving Drosophila seriema, Drosophila sp. B, D. koepferae and D. buzzatii strains were completely sterile while others involving strains from these species produced F1 hybrids that did not yield F2. In the present work, data on courtship duration and copula occurrence obtained in the analysis of flies from parental sterile crosses and on spermatozoon mobility observed in F1 hybrids that did not yield F2 are presented. Copula did not occur during one hour of observation and the spermatozoon also did not show mobility at any of the analyzed stages (3, 7,9 and 10 days old). There was a high variation in courtship average duration and in the percentage of males that courted the females. The reproductive isolation mechanisms indicated by these observations were pre and post-zygotic, as supported by the absence of copula and male sterility. Data obtained also showed the occurrence of different degrees of reproductive compatibility among the strains classified as the same species but from distinct geographic localities.
\end{abstract}

Key words: courtship, hybrids, male sterility in Drosophila.

\section{RESUMO}

\section{Avaliação da corte e da esterilidade do macho híbrido entre espécies do cluster de Drosophila buzzatii (Diptera, Drosophilidae)}

No grupo repleta de Drosophila, o estabelecimento de subgrupos e complexos realizado com base em evidências citológicas e morfológicas é suportado por testes de isolamento reprodutivo. Entre as espécies do grupo repleta, o cluster buzzatii, devido a seu politipismo e polimorfismo, é um excelente material para estudos ecológicos e de especiação. Alguns cruzamentos interespecíficos envolvendo linhagens de Drosophila seriema, Drosophila sp. B, D. koepferae e D. buzzatii foram completamente estéreis, enquanto outros produziram híbridos F1 que não deixaram F2. No presente trabalho são apresentados dados sobre a duração da corte e ocorrência de cópula dos intercruzamentos estéreis e dados sobre a mobilidade dos espermatozóides dos híbridos F1 que não deixaram F2. Não houve ocorrência de cópula no período de 1 hora de observação e os espermatozóides dos híbridos analisados 
não foram móveis em qualquer das idades testadas (3, 7, 9 e 10 dias de idade). Houve alta variação na duração média da corte e na porcentagem dos machos que cortejaram as fêmeas. A ausência de cópula e esterilidade dos machos F1 indica mecanismos pré e pós-zigótico operando entre as espécies desse cluster. Os dados também mostram diferentes níveis de compatibilidade reprodutiva entre linhagens classificadas como da mesma espécie mas de diferentes localidades geográficas.

Palavras-chave: corte, híbridos, esterilidade do macho em Drosophila.

\section{INTRODUCTION}

A good correlation between reproductive isolation and phylogenetic relationships has been found when groups of species are considered. In the Drosophila repleta group, the subgroups and their complex divisions established on the basis of morphological and cytogenetics evidence, have been supported by reproductive isolation tests (Crow, 1942; Wharton, 1944; Patterson, 1947; Wasserman, 1982, 1992).

Naveira \& Fontdevila (1991) studying hybrids in the repleta group showed that throughout the autosomes chromosomes of D. buzzatii and $D$. koepferae there are many non-allelic, minor sterility genes, whose individual segregation cannot be recognized phenotypically, and which act cumulatively on the same characteristics of spermatogenesis, each contributing a small effect to their disturbance in the hybrid male. Accordingly, these genes should be considered as polygenes, and the type of sterility they bring about ('minimum size effect') should be designated as polygenic sterility.

The male hybrid sterility is the most common post-zygotic reproductive isolation among related animal species, and, therefore, it has received special attention in the speciation studies (Zeng $\&$ Singh, 1995). In the last decade, the genetic basis of reproductive isolation has been shown to be surprisingly polygenic and recently several studies of reproductive isolation have been realized using molecular analysis. Extending the discovery of fertility rescue between Drosophila melanogaster and Drosophila simulans, Sawamura et al. (2000) showed that this hybridization could permit systematic and precise delineation of the genetic and molecular basis of speciation. These authors discovered at least six genes of hybrid male sterility and none for female sterility in a region of $5 \%$ of the $D$. simulans genome introgressed into $D$. melanogaster genome by deficiency mapping. Another work considering molecular data in the hybrid male sterility is the one developed by Dermitzakis et al. (2000). These authors introgressed regions of the Drosophila sechellia genome into $D$. simulans genome to identify and map genetic defects in interspecific hybrids. The data indicated that the sex ratio phenotype results from an epistatic interaction between at least two factors.

The differentiation among populations of geographically distinct species of buzzatii cluster has already been estimated using several forms of genetic variation: karyotype, reproductive isolation, chromosome inversions, aedeagus morphometry, fertility and fecundity, synapse degree in the polytene chromosomes, sexual isolation, esterase patterns, mitochondrial DNA, RAPD and satellite DNA (Vilela \& Sene, 1977; Baimai et al., 1983; Bizzo, 1983; Naveira et al., 1986; Tosi \& Sene, 1989; Naveira \& Fontdevila, 1991; Silva \& Sene, 1991; Madi-Ravazzi \& Bicudo, 1992; Moraes, 1992; Lapenta et al., 1995; Tidon-Sklorz \& Sene, 1995; Kuhn et al., 1996; Madi-Ravazzi et al., 1997; Manfrin et al., 2001; Monteiro, 1997; Lapenta et al., 1998; Castro \& Madi-Ravazzi, 2000; Kuhn et al., 1999; Machado et al., 2001, submitted).

This work intended to obtain additional data on the differentiation within the buzzatii cluster species, now focusing pre and post-mechanisms acting among the species.

\section{MATERIAL AND METHODS}

The species, strains and geographic regions used in this work are in Table 1.

In the text and tables the symbols of strains were shortened to the first letter plus the two following numbers, except for $D$. buzzatti strains for which R2 and R5 were used. 
TABLE 1

Species, strains, and geographic locality of strains utilized in the present study.

\begin{tabular}{|c|c|c|}
\hline Species & Strains & Locality \\
\hline \multirow[t]{2}{*}{ Drosophila sp. B } & A55F11 & Bela Vista (MS, Brazil) \\
\hline & B50Q3 & Ibotirama (BA, Brazil) \\
\hline \multirow[t]{7}{*}{ Drosophila seriema } & A95F3 & \multirow{2}{*}{ Serra do Cipó (MG, Brazil) } \\
\hline & $\mathrm{D} 40 \mathrm{~F} 1$ & \\
\hline & D62C4BM & \multirow{2}{*}{ Mucugê (BA, Brazil) } \\
\hline & D63M & \\
\hline & D71C1BM & \multirow{2}{*}{$\begin{array}{l}\text { Morro do Chapéu } \\
\text { (BA, Brazil) }\end{array}$} \\
\hline & $\mathrm{D} 72 \mathrm{M}$ & \\
\hline & D73C5BM & $\begin{array}{c}\text { Cachoeira do Ferro Doido (BA, } \\
\text { Brazil) }\end{array}$ \\
\hline \multirow[t]{2}{*}{ Drosophila koepferae } & B20D2 & Tapia (Tucuman, Argentina) \\
\hline & B25D7 & Famatina (La Rioja, Argentina) \\
\hline \multirow[t]{2}{*}{ Drosophila buzzatii } & D69R2 & \multirow{2}{*}{$\begin{array}{l}\text { Locality without name } \\
\text { (BA, Brazil) }\end{array}$} \\
\hline & D69R5 & \\
\hline
\end{tabular}

For the courtship study, 25 couples (with 8 days old) of each sterile cross were analyzed (Table 2). Each couple was put separately in tubes containing culture medium and was observed during one hour. The beginning and the end of the courtship were computed. The tubes were stored during a month for detecting the presence or absence of eggs and larvae, and then they were discarded. Control experiments were realized involving the observation of the courtship in intracrosses of all strains showed in Table 1 (Table 3). Mobility of the hybrid spermatozoon from sterile F1 intercrosses was tested using the technique described by Orr (1992), with modifications. Testes preparations of three, seven, nine and 10 days old males from the intracrosses and intercrosses were used as control (Table 4). Males were dissected in DEMEREC physiologic solution, and the testes were transferred to a slide containing a drop of the same solution. The preparations were covered with a covership, squashed and immediately examined in the light microscope.
In order to verify if the sterility of the F1 intercrosses was due to the hybrid male, hybrid males and females were retrocrossed with the parental.

\section{RESULTS AND DISCUSSION}

Copula did not occur during the observation period of the different intercrosses. A high variation in the percentage of males that courted the females was observed in the different intercrosses, ranging from $4 \%$ in the intercrosses of the D. buzzatii x D. koepferae (F D69 x M B20) to $44 \%$ in the crosses of females of the D. seriema (A95 and/or D73) versus males of the D. buzzatii R2 (Table 1). The males courted females more than once. The average of the courtship duration also showed variation, from 30 seconds up to 2 minutes, in the different intercrosses analyzed (Table 2). In the control intracrosses, after a brief period (few seconds, Table 3 ), the couples had already copulated. 
TABLE 2

Average duration in seconds and standard error of courtship between sterile cross couples, and couple percentage in which courtship occurred. $F=$ female, $M=$ male.

\begin{tabular}{|c|c|c|c|c|c|}
\hline \multicolumn{2}{|c|}{ Strains and crosses } & \multirow{2}{*}{\multicolumn{3}{|c|}{ Courtship average duration }} & \multirow{3}{*}{$\begin{array}{c}\text { Males percentage that } \\
\text { courted the females }\end{array}$} \\
\hline \multirow{2}{*}{$\begin{array}{c}\mathbf{F} \\
\mathrm{A} 95\end{array}$} & \multirow{2}{*}{$\begin{array}{l}\text { M } \\
\text { R2 }\end{array}$} & & & & \\
\hline & & 130.00 & \pm & 46.10 & \\
\hline $\mathrm{R} 2$ & A95 & 46.43 & \pm & 8.05 & $28 \%$ \\
\hline D62 & $\mathrm{R} 2$ & 30.30 & \pm & 13.60 & $8 \%$ \\
\hline $\mathrm{R} 2$ & D62 & 43.00 & \pm & 12.10 & $12 \%$ \\
\hline D71 & $\mathrm{R} 2$ & 39.25 & \pm & 3.20 & $20 \%$ \\
\hline $\mathrm{R} 2$ & D71 & 38.00 & \pm & 6.72 & $8 \%$ \\
\hline D72 & $\mathrm{R} 2$ & 59.50 & \pm & 22.70 & $12 \%$ \\
\hline $\mathrm{R} 2$ & D72 & 34.00 & \pm & 6.21 & $16 \%$ \\
\hline D73 & $\mathrm{R} 2$ & 49.90 & \pm & 12.00 & $44 \%$ \\
\hline $\mathrm{R} 2$ & D73 & 25.75 & \pm & 7.75 & $8 \%$ \\
\hline B50 & $\mathrm{R} 2$ & 53.41 & \pm & 9.92 & $24 \%$ \\
\hline R5 & B20 & 52.00 & \pm & 0.00 & $4 \%$ \\
\hline B20 & R5 & 28.80 & \pm & 5.62 & $12 \%$ \\
\hline
\end{tabular}

The absence of copula was observed in sterile couples indicating the pre-zygotic reproductive isolation. The importance of natural selection in reinforcing the isolation is evidenced by the fact that among the allopatric species or allopatric strains of different species the isolation is less strong than among sympatric strains or species (e.g. Dobzhansky et al., 1964; Grant, 1966). Our results relative to crosses of different strains of $D$. seriema with $D$. buzzatii are an example of this situation: the strains intercrossed are all allopatric in nature, but $D$. buzzatii is the only one among this species cluster that became cosmopolitan and can be found in sympatry in many regions with the others from the same cluster.

Thus, it may be supposed that the genetic divergence between $D$. seriema and $D$. buzzatii took place in allopatric populations that became sympatric and, when this happened, natural selection favored the reproductively isolated individuals, fixing, in this way, the isolation between the species.
The only asymmetric pre-zygotic isolation observed was between Drosophila sp. B (B50) and D. buzzatii (R2). However, the crosses among A55 (another strain of Drosophila sp. B) and the strains R2 and R5 of the D. buzzatii were fertile, showing that the females of this strain, differently of B50, did not discriminate males of strains of the D. buzzatii. This indicates variation between these strains of the same species, in this aspect Sureau \& Ferveur (1999) observed the male courtship behavior among Drosophila melanogaster strains of different geographical localities and noticed that the male courtship behavior is genetically controlled and influenced by sex pheromones [7-tricosene (7-T) induces a dose-dependent inhibition of male-male courtship, whereas 7,11-dienes stimulate male courtship of females]. They observed that there was a geographical quantitative variation in the production of two predominant male hydrocarbons, 7-T and 7 -pentacosene. These geographical differences in the hormone quantity could be responsible for the variation in the courtship between these two strains. 
TABLE 3

Intracrosses and average period and standard error in seconds that the couples copulated after put male and female together.

\begin{tabular}{|c|c|c|c|}
\hline Strains & \multicolumn{3}{|c|}{ Average period \pm SE } \\
\hline A55 & 20.00 & \pm & 0.00 \\
\hline B50 & 15.75 & \pm & 3.02 \\
\hline A95 & 18.90 & \pm & 1.60 \\
\hline D40 & 21.20 & \pm & 2.30 \\
\hline D62 & 23.10 & \pm & 3.01 \\
\hline D63 & 15.50 & \pm & 1.03 \\
\hline D71 & 16.92 & \pm & 3.72 \\
\hline D72 & 19.80 & \pm & 2.30 \\
\hline D73 & 17.95 & \pm & 2.95 \\
\hline B20 & 19.00 & \pm & 1.72 \\
\hline B25 & 20.14 & \pm & 2.20 \\
\hline R2 & 19.90 & \pm & 3.62 \\
\hline R5 & 17.93 & \pm & 1.08 \\
\hline
\end{tabular}

\section{TABLE 4}

Control intracrosses ( $\equiv$ ), control intercrosses ( |||| $\mid)$ and sterile F1 intercrosses $(\square)$ used to analyse the spermatozoon mobility. $\mathrm{F}=$ female, $\mathrm{M}=$ male.

\begin{tabular}{|c|c|c|c|c|c|c|c|c|c|}
\hline$F^{M}$ & A55 & A95 & B25 & B50 & D40 & D62 & D63 & D71 & $\mathbf{R 2}$ \\
\hline A55 & & & & & & & & & \\
\hline A95 & & & & & & & & & \\
\hline B25 & & & & & & & & & \\
\hline B50 & & & & & & & & & \\
\hline D40 & & & & & & & & & \\
\hline D62 & & & & & & & & & \\
\hline D63 & & & & & & & & & \\
\hline D71 & & & & & & & & & \\
\hline $\mathbf{R} 2$ & & & & & & & & & \\
\hline
\end{tabular}


Monteiro \& Sene (1995) had observed that each population of Drosophila sp. B can be discriminated, suggesting absence of gene flow between them. This could occur because these populations are found mainly in hills, forming true isolation. This fact could explain the differences found in the present work between the two strains of Drosophila sp. B. Moreover, Madi-Ravazzi et al. (1997) observed that the strain B50 showed a different behavior from the other Drosophila sp. B strains. This strain presented a low degree of reproductive compatibility with $D$. seriema.

In a review of the genus Drosophila, Bock (1984) listed 266 cases of interspecific hybri dization in the laboratory and also 8 reported cases of hybridization in nature. These data show that interspecific hybridization in this genus is not at all a rare phenomenon, at least under the artificial conditions of the laboratory. But, this and other articles (Madi-Ravazzi \& Bicudo, 1992; Marin et al., 1993; Madi-Ravazzi et al., 1997; Machado et al., 2001) also show clearly that the production of viable hybrids is restricted to the most closely related species. Our results agree with Marin et al. (1993) regarding reproductive differences between $D$. koepferae and D. seriema. Even the intercrosses between $D$. buzzatii and $D$. seriema strains and $D$. koepferae were sterile in both directions of crosses. Besides, the intercrosses between, Drosophila sp. B females (B50) and D. buzzatii males (R2) also were sterile, but, the reciprocal crosses were fertile. However data obtained by Marin et al. (1993) showed inverse fertility, that is, D. buzzatii females with Drosophila sp. B males, using different strains of that used in this work.

In the present study the spermatozoon mobility analysis of males derived from control intra- and intercrosses showed little or no mobility in most of the 5-day old males, a relative mobility in the 7-day old males, and a high mobility in 9-day old males. The sterile hybrid males resultant of three intercrosses did not show mobile spermatozoa in all tested ages. Another fact that indicates the male sterility is the backcrosses carried out between these males and the parental females. These crosses were also sterile, while the backcrosses between the F1 females and parental males were fertile.

Bizzo (1983) also showed post-zygotic isolation between allopatric populations of species included in the D. buzzatii cluster. He showed that mass intercrosses between A95 isofemale strain and B53 strain (Milagres, BA) produced sterile males and fertile females in both cross directions. Wasserman \& Richardson (1987), also using species of buzzatii cluster, found another example of allopatric species that showed post-zygotic isolation. The reciprocal crosses between allopatric populations of $D$. serido and D. koepferae produced fertile females. However, when $D$. serido females were used, the male offspring was sterile, while in the reciprocal cross the males were fertile.

The rule of Haldane considers that in cases of unisexual inviability and sterility, the heterogametic sex is more affected. Several authors had considered models to explain the rule of Haldane (Charlesworth et al., 1987; Coyne \& Orr, 1989; Hollocher \& Chung-I, 1996; Turelli \& Orr, 2000, for example). Several studies have shown that $\mathrm{X}$ chromosome, by itself, has the greatest role in the sterility of hybrid male, exerting its effect by the interaction with genes of other species. The genes that interact with heterospecific $\mathrm{X}$ chromosome can be in the autosomes, the $\mathrm{Y}$ chromosome or cytoplasm (when the females are heterogametic) (Coyne \& Orr, 1989; Zouros, 1989).

Dobzhansky (1936), who studied hybrid sterility in Drosophila pseudoobscura had already observed that the causes of hybrid sterility remained one of the unsolved problems of biology. It seems that this problem, besides advances in the molecular area, still has many questions to be answered.

The hybrid sterility, by itself, is not an adaptive phenotype, but a pleiotropic effect of several unknown factors. Thus, the genetic of the sexual isolation would be more representative of divergent species, and the sexual isolation characteristics are most probably products of adaptive evolution rather than of hybrid sterility (Hollocher et al., 1997).

In the present study the reproductive behavior showed that distinct strains classified as same species presented differences in female discrimination regarding the males courtship. However, the finding of this intraspecifically achievement needs the support of other markers to distinguish between intraspecific or interspecific differences. The hybrid male sterility is an important subject and studies focusing on the genetic and cellular aspects of spermatogenesis must be the next step to improve our analysis. 
Acknowledgments - Credits are due to Dr. Fábio de Melo Sene for providing the strains used, to Dr. Hermione Elly Melara de Campos Bicudo for improving the English, to CNPq. for a Fellowship given to L. P. B. Machado, and to FUNDUNESP and CAPES for financial support.

\section{REFERENCES}

BAIMAI, V., SENE, F. M. \& PEREIRA, M. A. Q. R., 1983, Heterochromatin and karyotypic differentiation of some neotropical cactus - breeding species of the Drosophila repleta species group. Genetica, 60: 81-90.

BIZZO, N. M. V., 1983, Estudos sobre a biologia $e$ isolamento reprodutivo em $\mathrm{D}$. serido. Dissertação de Mestrado, Instituto de Biociências, Universidade de São Paulo, São Paulo, p. 71.

BOCK, I. R., 1984, Interspecific hybridization in the genus Drosophila. Evol. Biol., 18: 41-70.

CASTRO, J. P. \& MADI-RAVAZZI, L., 2000, RAPD as genetic marker in taxonomic and evolutionary studies in the Drosophila buzzatii cluster. Drosophila Information Services (DIS), 83: 26-32.

CHARLESWORTH, B., COYNE, J. A. \& BARTON, N. H., 1987, The relative rates of evolution of sex chromosomes and autosomes. Am. Nat., 130: 113-146.

COYNE, J. A. \& ORR, H. A., 1989, Patterns of speciation in Drosophila. Evolution, 43: 362-381.

CROW, J. F., 1942, Cross fertility and isolation mechanisms in the Drosophila mulleri group. University of Texas Publications, 4228: 53-67.

DERMITZACKS, E. T., MASLY, J. P., WALDRIP, H. M. \& CLARK, A. G., 2000, Non-Mendelian segregation of sex chromosomes in heterospecific Drosophila males. Genetics, 154: 687-694.

DOBZHANSKY, T., 1936, Studies on hybrid sterility. II. Localizations of sterility factors in Drosophila pseudoobscura hybrids. Genetics, 21: 113-135.

DOBZHANSKY, T., EHRMAN, L., PAVLOVSKY, O. \& SPASSKY, B., 1964, The superspecies Drosophila paulistorum. Proc. Natl. Acad. Sci. U.S.A., 51: 3-9.

GRANT, V., 1966, The selective origin of incompatibility barriers in the plant genus Gilia. Am. Nat., 100: 99-118.

HOLLOCHER, H. \& WU, S.-I., 1996, The genetics of reproductive isolation in the Drosophila simulans clade: $\mathrm{X}$ vs. Autosomal effects and male vs. Female effects. Genetics, 143: 1243-1255.

HOLLOCHER, H., TING, C.-T., WU, M.-L. \& WU, C.-I., 1997, Incipient speciation by sexual isolation in Drosophila melanogaster: extensive genetic divergence without reinforcement. Genetics, 147: 1191-1201.

KUHN, G. C. S., RUIZ, A., ALVES, M. A. R. \& SENE, F. M., 1996, The metaphase and polytene chromosomes of Drosophila seriema (repleta group; mulleri subgroup). R. Bras. Gen., 19: 209-216.
KUHN, G. C. S., BOLLGÖNN, S., SPERLICH, D. \& BACHMANN, L., 1999, Characterization of a speciesspecific satellite DNA of Drosophila buzzatii. J. Zool. Syst. Evol. Research, 37: 109-112.

LAPENTA, A. S., BICUDO, H. E. M. C., CERON, C. R. \& MANZATO, J. A., 1995, Esterase patterns of species in the Drosophila buzzatii cluster. Cytobios, 84: 13-29.

LAPENTA, A. S., BICUDO, H. E. M. C., CERON, C. R. \& CORDEIRO, J. A., 1998, Esterase patterns and phylogenetic relationships of species and strains included in the Drosophila buzzatii cluster. Cytobios, 96: 95-107.

MACHADO, L. P. B., MADI-RAVAZZI, L. \& TADEI, W. J., 2001, Reproductive relationships and synapsis degree in the polytene chromosomes of Drosophila buzzatii species cluster. Submitted to Genetica/Holland.

MADI-RAVAZZI, L. \& BICUDO, H. E. M. C., 1992, Differentiation of Drosophila serido (isofemale line A95F3) and D. koepferae (isofemale line B20D2) reproductive isolation, development time and polytene chromosome banding patterns. Rev. Bras. Gen., 15: 831-851.

MADI-RAVAZZI, L., BICUDO, H. E. M. C. \& MANZATO, J. A., 1997, Reproductive compatibility and chromosome pairing in the Drosophila buzzatii complex. Cytobios, 89: 21-30.

MANFRIN, M. H., DE BRITO, R. O. A. \& SENE, F. M., 2001, Systematics and evolution of the Drosophila buzzatii cluster (Diptera: Drosophilidae) using mt DNA. Ann. Entomol. Soc. Am., 94: 333-346.

MARIN, I., RUIZ, A., PLA, C. \& FONTDEVILA, A., 1993, Reproductive relationships among ten species of the Drosophila repleta group from South America from the West Indies. Evolution, 47: 1616-1624.

MONTEIRO, S. G., 1997, Morfometria multivariada de populações naturais de Drosophila serido. Tese de Doutorado em Genética, Faculdade de Medicina, Universidade de São Paulo, Ribeirão Preto, p. 108.

MONTEIRO, S. G. \& SENE, F. M., 1995, Estudo morfométrico de populações de Drosophila serido das regiões central e sul do Brasil. Rev. Bras. Gen., 18: 283.

MORAES, M. A. M., 1992, Isolamento sexual entre populações da superespécie Drosophila serido (Diptera, Drosophilidae). Dissertação de Mestrado, Instituto de Biociências, Universidade de São Paulo, São Paulo, p. 91.

NAVEIRA, H. \& FONTDEVILA, A., 1991, The evolutionary history of Drosophila buzzatii. XXI. Cumulative action of multiple sterility factors on spermatogenesis in hybrids of D. buzzatii and D. koepferae. Heredity, 67: 57-72.

NAVEIRA, H., PLA, C. \& FONTDEVILA, A., 1986, The evolutionary history of Drosophila buzzatii. XI. A new method for cytogenetic localizaton based on asynapsis of polytene chromosomes in interspecific hybrids of Drosophila. Genetica, 71: 199-212.

ORR, H. A., 1992, Mapping and characterization of a 'speciation gene' in Drosophila. Genetical Research, 59: $73-80$. 
PATTERSON, J. T., 1947, Sexual isolation in the mulleri subgroup. University of Texas Publications, 4720: 32-40.

SAWAMURA, K., DAVIS, A. W. \& WU, C.-I., 2000, Genetic analysis of speciation by means of introgression into Drosophila melanogaster. Proc. Natl. Acad. Sci. USA, 97: 2652-2655.

SILVA, A. F. G. \& SENE, F. M., 1991, Morphological geografic variability in Drosophila serido (Diptera, Drosophilidae). Rev. Bras. Entomol, 35: 455-468.

SUREAU, G. \& FERVEUR, J. F., 1999, Co-adaptation of pheromone production and behavioural responses in Drosophila melanogaster males. Genet. Res., 74: 129-137.

TIDON-SKLORZ, R. \& SENE, F. M., 1995, Drosophila seriema n. sp.: New Member of the Drosophila serido (Diptera: Drosophilidae) Superspecies Taxon. Annals of the Entomological Society of America, 88: 139-142.

TURELLI, M. \& ORR, H. A., 2000, Dominace, epistasis and the genetics of postzigotic isolation. Genetics, 154: 16631679.

TOSI, D. \& SENE, F. M., 1989, Further studies on chromosomal variability in the complex taxon Drosophila serido (Diptera, Drosophilidae). Rev. Bras. Gen., 12: 729-745.
VILELA, C. R. \& SENE, F. M., 1977, Two new neotropical species of D. repleta group of the genus Drosophila (Diptera, Drosophilidae). Pap. Avulsos Zool., 30: 295-299.

WASSERMAN, M., 1982, Evolution of the repleta group. pp. 61-139. In: M. Ashburner, H. L. Carson \& J. N. Thompson (eds.), The genetics and biology of Drosophila. Academic Press., London.

WASSERMAN, M., 1992, Cytological evolution of the Drosophila repleta species group. pp. 455-533. In: J. R. Powell \& C. B. Krimbas (eds.), Inversion polymorphism in Drosophila. CRC Press. Inc., Boca Raton.

WASSERMAN, M. \& RICHARDSON, R. H., 1987, Evolution of Brazilian Drosophila mullericomplex species. J. Hered., 78: 282-286.

WHARTON, L. T., 1944, Interspecific hybridization in the repleta group. University of Texas Publications, 4445: 175-193.

ZENG, L. W. \& SINGH, R. S., 1995, A general method for identifying major hybrid male sterility genes in Drosophila. Heredity, 75: 331-341.

ZOUROS, E., 1989, Advances in the genetics of reproductive isolation in Drosophila. Genome, 31: 211-220. 